\title{
Symbolic space on the old maps of Silesia (16th-18th c.)
}

\section{Teresa Bogacz}

$\mathbf{T}_{\mathrm{r}}^{\mathrm{k}}$ he closer to the beginnings of the European cartography, the more legible its connections with culture become. The cartography of the pre-measured period, which was eventually brought to an end by the outbreak of the French Revolution ${ }^{1}$, reflected both the social needs related to space exploring and imaging and the level of expertise and artistry of the authors of the maps ${ }^{2}$. This, from the historical point of view, is closed in the wider concept of culture. Along with the transition to the measuring system, cartography basically eliminated its humanistic features and became a specialized field, almost inseparably associated with the exact sciences.

The filling of the old maps with cultural content can be found mainly in their rich graphic design and text layer both conforming to conventions and artistic methods applicable at that time. The metaphorical and symbolic layer which affected the mental, ideological and religious spheres of both the creators and the consumers (towards whom it was directed) played an important role in the process of space imaging. Like all the signs, symbols hide the content legible primarily for individuals and groups which create them ${ }^{3}$. The symbolics of the maps was created mainly by a specific method of presenting selected areas which combined standard information transfer (like topography) with deeper ideological message. Cultural and spiritual contents (concerning mainly cultivation of the past and the tradi-

\footnotetext{
${ }^{1}$ J. Janczak (Zarys dziejów kartografii śląskiej do końca XVIII wieku, Opole 1976, p. 37) closed this stage in 1720 , when the first topographic measurements on Silesia were made at the request of the Austrian Emperor Charles VI.

${ }^{2}$ This aspect of former cartography became an area of interests for art historians. One of the examples can be a work of B. Czechowicz (Historia kartografii Śląska XIII-XIX wieku. Wrocław 2004) written from that research option. T. Bogacz and B. Konopska (Motywy kartograficzne w medalierstwie polskim, in: Dwudziestolecie Zespołu Historii Kartografii przy Instytucie Historii Nauki PAN, ed. J. Ostrowski, W. Wernerowa, Warszawa $1995<$,Z Dziejów Kartografii”, t. 7>, pp. 99-124) paid
}

tion, strengthening and building the identity with the area, creating its local characteristics as well as searching and discovering its cultural identity) are related to the above mentioned form of the symbolic space.

The symbolic space along with semantic and axiological codes has found its special place in the European regional cartography, starting from the earliest maps. It marked its presence on the maps of historical and geographical regions, formed in the natural process of development, in a very interesting way. The inhabitants of those regions have a high degree of regional awareness and a significant cultural heritage. Therefore, they felt the need for spatial visualization of those values. Among those areas we can find Silesia. In this paper (based on selected maps of Silesia and plans of Wroctaw - from $16^{\text {th }}$ to $18^{\text {th }}$ centuries) the author brought closer the various spaces that implemented those specific needs of identification with the area or cultural diversity selection. An additional aim of this paper is to show how the former Silesian cartography helped to create the image of this culturally rich and unique region.

\section{Educational and intellectual ambitions}

One of the earliest examples of "the area with the message" can be found on the first map of Silesia from 1561, by Martin Helwig from $\mathrm{Nysa}^{4}$. His work has not only the advantage of originality due to the fact that the cartog-

attention to different aspect of searching for the relationships between cartography and art.

${ }^{3} \mathrm{~J}$. Monnet, The symbolizm of place: a geography of relationships between space, power and identity. „Cybergeo: European Journal of Geography", article 562 (http://cybergo.revues.org/24747, 3 IV 2013), paragraph 1.

${ }^{4}$ The author of the article used a map reproduction from the 1776 edition which is a part of Wroctaw "Ossolineum" Library collection. It is placed in the following publication: Katalog dawnych map Rzeczpospolitej Polskiej w kolekcji Emeryka Hutten Czapskiego i w innych zbiorach, t. 1 : Mapy XV i XVI wieku, elaborated by W. Kret, Wrocław 1978, attch. map no 21. 
rapher made his own measurements ${ }^{5}$, but it also reflects the high level of regional awareness of the Silesian Renaissance elites and their intellectual aspirations. Therefore, it is not a coincidence that the author located - apparently the first in the history of Silesia - school in Smogorzów near Namysłów and provided the following record: Smogra, prima Silesiorum schola - 966 (Fig. 1). He probably used there

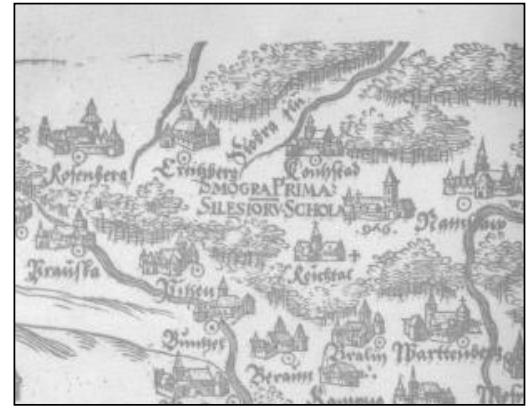

Fig.1. Fragment of Helwig's map of Silesia from "Katalog dawnych map Rzeczypospolitej"

the information (given by Jan Długosz in his "Polish Histories") that after receiving baptism in 996, Duke Mieszko I immediately established in the country nine bishoprics, which were supposed to help to maintain and expand the Christian faith ${ }^{6}$. The village Smogorzów, which gave the origins to the later bishopric of Wrocław ${ }^{7}$, became one of the seats of the new administration. Helwig concluded that if there was a bishopric there had to be a school because the first educational institutions were organized by the cathedral churches.

Not fully reliable information provided by Długosz was eagerly used by the author of the first map of Silesia and probably also by his patron, Nikolaus Rehdiger to whom Helwig dedicated the map. In the era of Renaissance the Rehdiger family belonged to the most powerful patrician families with humanistic and patronage ambitions.

With this information Helwig also completed one of three goals he set for himself. Except for making the travel easier and being helpful while reading other cartographic works, his map of Silesia was supposed to help to understand better the older and more recent history of the region ${ }^{8}$.

The fact that Martin Helwig's record needed correction can be proved by the information provided in the first economic map of Silesia from 1973, written by Carl Hentschel from Legnica?. The map was published as an annex to a small booklet dedicated to the Silesian economy.

Smogorzów was also reported on the map as a space, symbolic for the region, but the note: Smogra, prima sedis Episcopi Silesiaci Ao 966 - the first diocesan residence in Silesia (Fig. 2) seems to be closer to the truth.

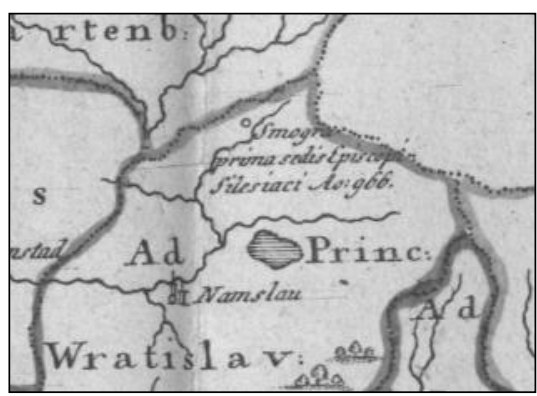

Fig. 2. Fragment of K.F. Hentschel's map of Lower Silesia

Regardless of how the authors of old maps perceived or wanted to perceive the Silesian education and intellectual traditions, the indication itself is very meaningful and is a reflection of the ambitions to be kept in mind by the future generations of Silesians as well as the popularization of these traditions to the wider audience.

${ }^{5}$ D. Przybytek, Kartografia historyczna Śląska XVIII-XX wieku, Wrocław 2002, p. 23

${ }^{6}$ Polska Jana Długosza, red. H. Samsonowicz, Warszawa 1984, p. 86. ${ }^{7}$ Historians carefully situate the first bishopric in 968 , highlighting its contemporary missionary nature (see Polska Jana Długosza, p. 86, index 30).

${ }^{8}$ J.Janczak, Zarys dziejów kartografii śląskiej, p. 47.

${ }^{9}$ Ducatus Silesiae. Tabula prima Silesiam Inferiorem continens. in: Historisch-geographische Anzeige der natürlichen, industriellen und künstlichen Produckte Schlesiens und der Grafschaft Glatz Hentschel, von K.F., Breslau bey 1793. Special collection of the Library of University of Wrocław, inventory no. 303 206. The map along with the brochure was "discovered” for the history of Silesian cartography by J. Janczak (1990, pp. 3-9) who gave their first characteristic. 


\section{The cultural identity with the area}

Another example of symbolic space which can also be found on the map by Martin Helwig is considered to be an excellent illustration of the relationships that exist between space (in this case topographical features) and contents and

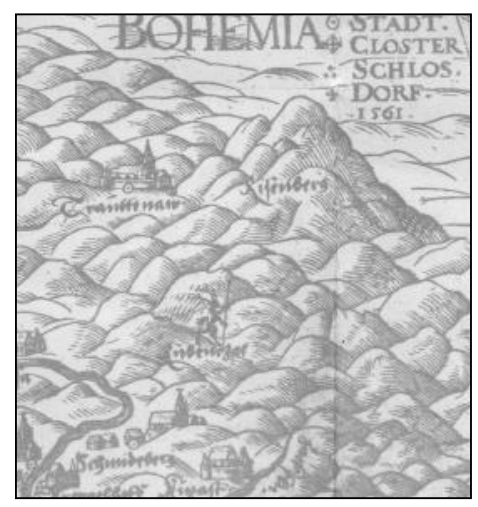

Fig. 3. Fragment of Helwig's map of Silesia from "Katalog dawnych map Rzeczypospolitej"

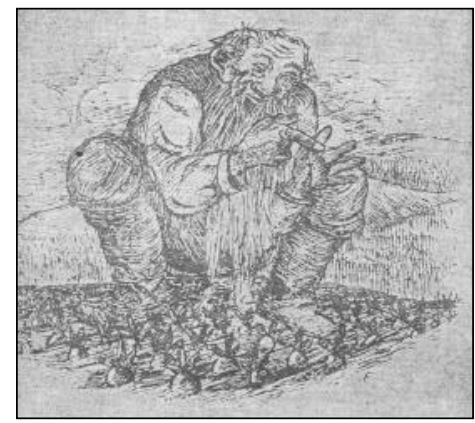

Fig. 4. Liczyrzepa, in: J. Janczak, "Z kuferkiem i chlebakiem", p. 12

forms in culture and art. The first cartographer of Silesia placed the earliest image of Rübenzahl among the peaks of the Karkonosze Mountains. Rübenzahl is a mountain spirit, folk tales protagonist and an inhabitant of mass imagination of many generations of Silesians. His rather not appealing image did not result from the lack of liking from Helwig ${ }^{10}$, but it reflected the image of him from the Silesians point of view. He attributed both demonic features - deer antlers, hooves, tail and human features - Mountain Spirit as a thoroughbred wanderer holds a magnificent rod in his hands (Fig. 3).

Looking at later presentations of the Sudetes ruler, also known as Liczyrzepa in Polish, one can see his metamorphosis towards full humanization which allowed him (in the light of myths and legends) to be close to people and offer them help ${ }^{11}$ (Fig. 4).

\section{The memory of the spiritual and material values}

Weiner's (father and son named Barthel 1562) first plan of Wrocław comes from the same period as Helwig's map ${ }^{12}$. On its edge, in the upper right corner, the Premonstratensian abbey foundation was recreated. Until 1529 the abbey has been located on the north bank of the Oder River, on the Olbin. This specific reconstruction was presented with the information about the circumstances

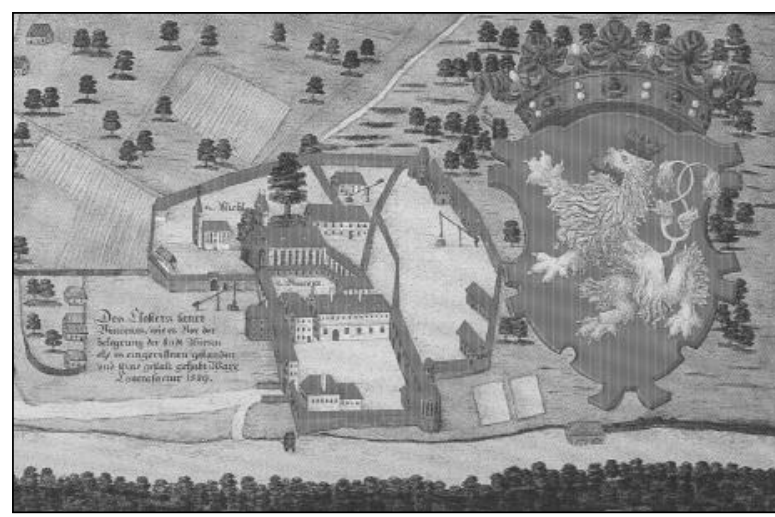

Fig. 5. Fragment of Weiner's plan of Wrocław according to Partsch's reproduction from 1826

and the time of the demolition of the objects displayed on the map (Fig. 5). The Benedictine Abbey along with St. Vincent Church

${ }^{10} \mathrm{~J}$. Janczak, Z kuferkiem i chlebakiem. Kartki o przeszłości uzdrowisk i turystyki śląskiej, Wałbrzych 1982, p. 13.

${ }^{11}$ J. Janczak, Spotkania z Duchem Gór. Sudeckie szkice historyczne, Wrocław 1991.

${ }^{12}$ The author used a reproduction in K. Szykuła and co-authors catalogue (K. Szykuła i in., Wrocław na planach. XVI-XX wiek, ed. H. Okólska, Wrocław 1999). 
were founded in the $12^{\text {th }}$ century by Piotr Włostowic, the first Silesian to be known by the history and the influential palatine of Bolesław Krzywousty. At the same time this was the location of his court. The monastery complex along with a beautiful Romanesque basilica were described in 1512 by Bartłomiej Stein, Silesian geographer ${ }^{13}$. At the time when the map was published the monastery complex had not existed in the city landscape for decades. However, the role it had played in its history, not only in the religious or spiritual sense but also in the architectural and settlement ones, was significant enough to restore its memory.

Weiner's contributions were reinforced by a great archaeologist and architecture historian Edmund Małachowicz with yet another aspect. It was him who pointed to the fact that this was "the most reliable view of the St. Vincent Abbey made - 33 years after the destruction - of the memories, autopsy or the unknown contemporary iconography" ${ }^{\prime 4}$.

Another example of suggestive space, symbolizing material status and prestige of one of the cities located in Silesia - Złotoryja, can be found on the first map of central Europe from approximately 1464 . The author of the map was Cardinal Nicholas from Kuza, also called Kuzańczyk. This presently inconspicuous city had a great history associated with the exploitation of gold. The history is the reason why (until 1945) the city was called Goldberg.

The ores were extracted mainly from the slopes of Wilcza Góra (located nearby) probably at the turn of the $11^{\text {th }}$ and $12^{\text {th }}$ centuries. As for the techniques then, the exploitation must have been fairly intensive because at the turn of the $13^{\text {th }}$ and $14^{\text {th }}$ centuries all the deposits were exhausted. But those two hundred years were enough for the city to build its fame and attract widespread publicity.

People remembered about the Złotoryja "Gold Rush" for a long time also beyond the borders of the region ${ }^{15}$. News on this topic probably reached Kuzańczyk himself. Otherwise, it would be difficult to understand why within Silesia (a region full of rich, populous and administratively important cities) the author put on the map only two following cities: the capital - Wrocław (Wratislavia) and modest Złotoryja (Goldberg) (Fig. 6 ).

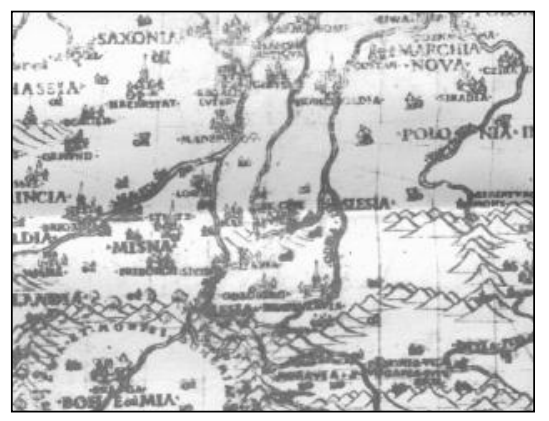

Fig. 6. Fragment of Cusanus' map of Europe, Eichstatt 1491. Reproduction of Parisian copy, published in "Katalog dawnych map Rzeczypospolitej", attachment no. 17

\section{Space as a symbol of the rule of law}

The above-mentioned theme (concerning space imaging) can be found on the plans of many Silesian cities of the feudal period. Usually, the penalties were administered either on the market or on the outskirts of the city. This practice became more and more frequent since the late $15^{\text {th }}$ century. On the maps they were identified by devices such as a pillory, a cage for criminals or gallows. On the Głogów city map (which is the reconstruction of spatial arrangement from the early $16^{\text {th }}$ century and made after 1758) one can see that the abovementioned devices were located beyond the urban areas (Fig. 7) ${ }^{16}$.

The inhabitants of Wrocław made a similar decision. They established new places de-

${ }^{13}$ Barttomieja Steina renesansowe opisanie Wroctawia. Die Beschreibung der Stadt Breslau der Renaissancezeit durch Bartholomäus Stein, ed. R. Żerelik, Wroctaw 1995, p. 28.

${ }^{14}$ E. Małachowicz, Najnowszy zarys dziejów najstarszego Wrocławia, Wrocław 2000, p. 71.

${ }^{15} \mathrm{~J}$. Janczak, Złotoryja i jej okolice na najstarszych mapach Śląska, Legnica-Złotoryja 1984, p. 4; R. Gładkiewicz, Dzieje Złotoryi, Złotoryja-Wrocław 1997, pp. 52-53.

${ }^{16}$ R. Wytyczak Śląsk w dawnej kartografii. Obraz Śląska na mapach XVI-XVIII wieku w zbiorach Zakładu Narodowego im. Ossolińskich we Wrocławiu, Wrocław 1998, p. 148, catalogue pos. 106. 
signed to enforce court judgments in the mid$16^{\text {th }}$ century. The place was located on Błonie Swidnickie and it freed the market square from this function. The new spot was found

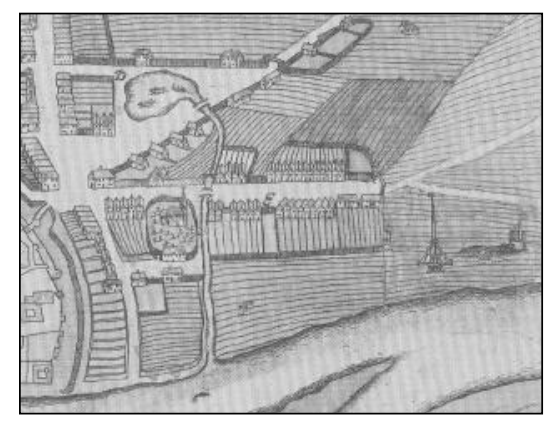

Fig. 7. Fragment of Gtogów city map

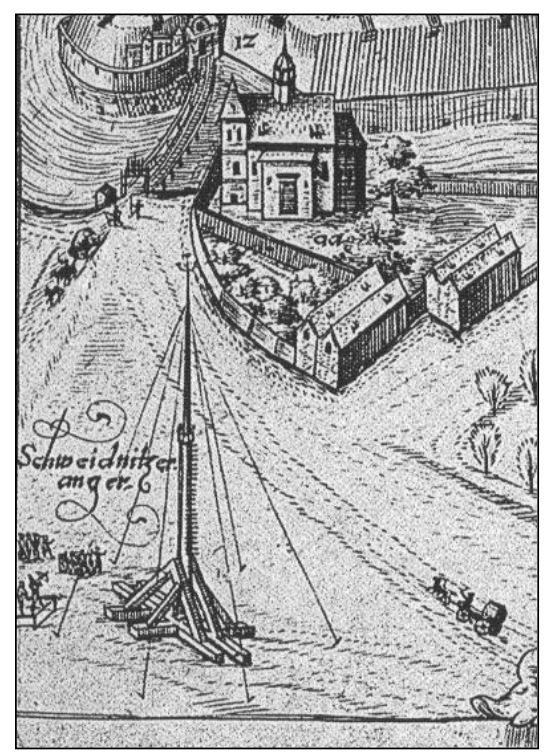

Fig. 8. Fragment of Wrocław city map by G. Heyer

at the south city entry near the present-day "Renoma" department store ${ }^{17}$.

On the plan of the Silesian Metropolis from $1591^{18}$ the imagination of George Heyer (its author) sailed much farther than in the case of earlier or later cartographers. It is very rare that one can encounter such literalism and imagery on maps - which in this case pictured an execution scene (Fig. 8). It seems that Heyer wanted to give to this place special importance by bringing it closer not in the static but in the dynamic way. The headsman holding a raised ax and his victim along with the focused (perhaps in anticipation of the act of God's justice) audience were on the one hand participants of this theatrical performance in a suburban setting. However, on the other hand one might see a different, more noble intention of the cartographer who wanted to see that place as sacred space (sacrum). Its symbolic meaning is increased by the collision of the event full of celebration with everyday life in the city (which was treated as a profane space). On the plan, one can in fact see the cars leaving and entering the city. This was probably supposed to help others realize that life goes on, keeping its regular and unchanging rhythm, and is filled with trivial solicitation.

\section{The phenomenon of garden-signature of Wrocław}

At the end of the $16^{\text {th }}$ century an intellectual and artistic event took place in Wrocław. It became famous far beyond the borders of Silesia. The above mentioned event was the opening (approximately in $1590^{19}$ ) of not only a fairy tale but also as a useful garden on the southeastern outskirts of the city. The garden itself was an absolutely unique place that could provide people not only with a stimulus to a deep philosophical reflection, contemplation, poetic moods and dreams but could also allow to feed sight with the view of plants created by nature in order to be impressed by them and make use of them in need ${ }^{20}$. This spatially small garden complex (6 acres) was

\footnotetext{
${ }^{17}$ More information on this subject, including detailed topography of the primary location of the place of penalties administration in Wroctaw, as well as later changes, can be found in the work of Maciej Trzciński, Miecz katowski, pręgierz, szubienica. Zabytki jurysdykcji karnej na Dolnym Śląsku (XIII-XVIII w.), Wrocław 2001, pp. 220-224.

${ }^{18} \mathrm{~K}$. Szykuła i in., Wrocław na planach, pos. 6.

${ }^{19}$ The exact date is unknown. It is assumed that the garden opening took place sometime between 1587 and 1590. See: G. Scheuermann, Das Breslau Lexicon, Bd 2, Dülmen 1994, p. 1529; Encyklopedia Wrocławia, ed. J. Harasimowicz, Wrocław 2006, p. 613; B. Czechowicz, Historia kartografii Śląska, p. 35.

${ }^{20}$ T. Bogacz, M. Cetwiński, E. Kościk, Wrocławskie anegdoty, Wrocław 1996, p. 25.
} 
the work of Laurentius Scholtz - a medic from Wrocław. Among the people who admired the garden one can find Esprinchard Jacques - the French traveler staying in Wrocław in 1597, who described it in his itinerarium ${ }^{21}$. The garden was located between today's Piotra Skargi and Wierzbowa streets at the place of a currently empty area (following the demolition

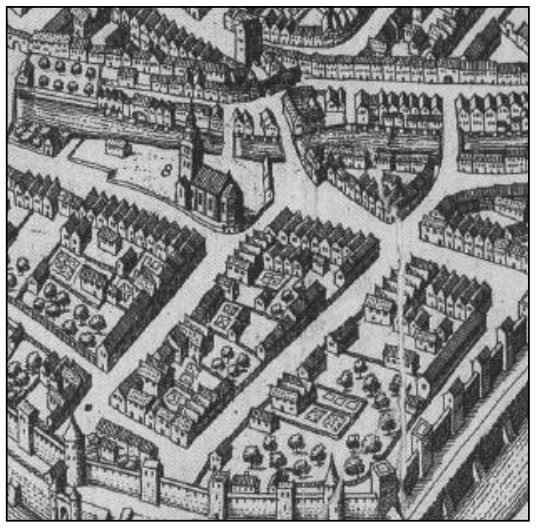

Fig. 9. Fragment of Wrocław city map by M. Merian

of Wrocław Graphic Works). One can find in the literature several voices of regret, pointing to the fact that on Heyer's plan we lacked this magnificent product of the contemporary garden and architectural $\mathrm{art}^{22}$. However, it seems that it could not have been placed there at that time. But a few years later (1598) Heyer portrayed on the copperplate the observation plan of master Scholtz's garden.

However, on the cartographic images of Wroctaw from the $17^{\text {th }}$ century one can see a clear indication of garden greenery on the former premises of Scholtz. This was not the first garden formation in this area but it had a slightly different character and purpose: first - Pharmaceutical Garden, and then the famous Wrocław Water Garden - owned by a lawyer - Wolfgang Scharschmidt. The other one can be seen on M. Merian's plan made before 1650 (Fig. 9) ${ }^{23}$.

In 1725, Countess von Lamberg became the owner of the property in Wierzbowa Street. Five years later a beautiful palace and Lusthaus were built here. The whole garden complex belonged to the most impressive fruitions in the $18^{\text {th }}$ century Wrocław. It existed at least till 1782 - before the area began to be built extensively ${ }^{24}$. On Seutter's plan (created between 1720 and 1730) we can find a repetitious image of a piece of Wrocław magical space. And on the F.B. Warner's plan we can see splendid Lamberg's garden along with a new palace and a rest house (Fig. 10).

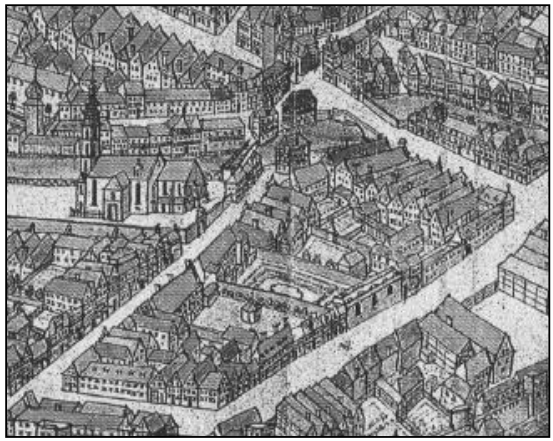

Fig. 10. Fragment of Wrocław city map by F.B. Werner

Even though in the $16^{\text {th }}$ century the gardens were nothing new in the landscape of Wroctaw (in the first half of the century the city had garden plans with botanical garden characteristics ${ }^{25}$, only the Laurentius Scholtz garden brought along a legend of this particular place, which was strengthened for many decades also through cartographic images of Wrocław. This sociological phenomenon enclosed in a small symbolic space found its

\footnotetext{
21 "I have also seen Wawrzyniec Scholtizius, a very famous doctor of medicine who showed many rarities (similar to those owned by Paludanus in Enkhuisen) kept not only in his house but also in the beautiful garden, decorated with a beautiful indoor painted and gilded gallery and a few other similar rooms", in: B. Geremek, Relacja Jakuba Esprincharda z podróży przez Śląsk i Matopolskę, „Kwartalnik Historii Kultury Materialnej", 7 (1959), no 3, p. 445.

22 P. Oszczanowski, Wrocławski ogród Laurentiusa Scholtza St. (15521599), in: Śląska Republika Uczonych. Schlesische Gelehrtenrepublik. Slezská Vědecká Obec, vol. 1, ed. M. Hałub, A. Mańko-Matysiak, Wrocław 2004, p. 106.

${ }^{23} \mathrm{~K}$. Szykuła i in., Wrocław na planach, pos. 8.

${ }^{24}$ W. Brzezowski, Ogrody barokowego Wrocławia, „Architectus”, 2003, no 1-2, pp. 70-73.

${ }^{25}$ W. Brzezowski, Ogrody barokowego Wroctawia, p. 69.
} 
exponent not only in the reconstruction of Scholtz's garden plans in 1913, but also had a significant impact on the perception of Wrocław as a city of flowers and greenery.

\section{Real and created space}

One can come across another kind of forming a symbolic dimension from the area. We can observe that on the map created by Johann Jacob Lidl - a Viennese cartographer around $1745^{26}$. Looking at the north-western part of Lower Silesia one can get the impression that the author created a map whose shape is not entirely real (Fig. 11). Świebodzińska

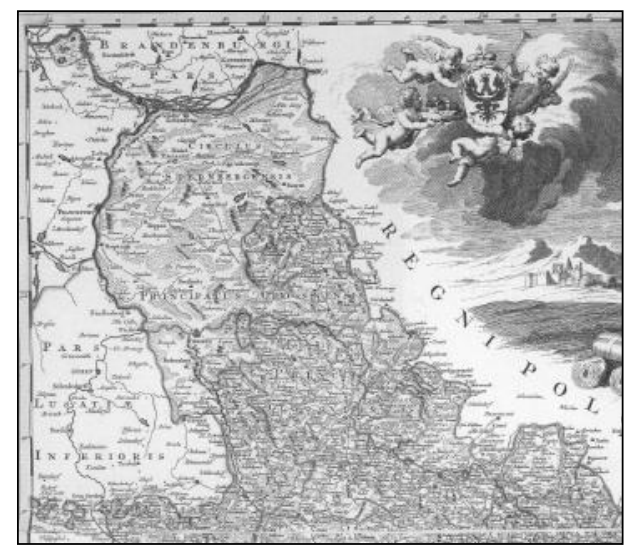

Fig. 11. Fragment of the Silesia map by J. Lidl

enclave, which was administratively excluded from the region at the beginning of the $19^{\text {th }}$ century, was rebuilt with the boarder suggesting a different range of the Silesian territory. The nomenclature that was used can indicate a sentimental and even visionary reconstruction of the Silesian border limits. Recalling Krośnieński duchy (Principatus Crosnensis) for the area included in the state of Brandenburg in 1492 at that time should rather be considered as anachronism. However, it is not known whether this space was created by the cartographer deliberately or was rather the result of compilations and modifications (in this case, earlier maps of J. Wieland and M. Schubarth). Perhaps this map should be read in terms of political propaganda, setting up boundaries or even as an illustration of law and $\operatorname{order}^{27}$.

For a comparison one can use another example of illustrating the region at the same time. The map of Tobias Meyer (1749) published in the Silesian Atlas in 1752 can be considered as that illustration ${ }^{28}$. It belonged to the first mathematically accurate cartographic representations of Silesia ${ }^{29}$. There is no symbolism in the compared area. There are realities showing inter alia current political and administrative divisions (Fig. 12).

Another example of different views of the same area can be pointed on two plans of

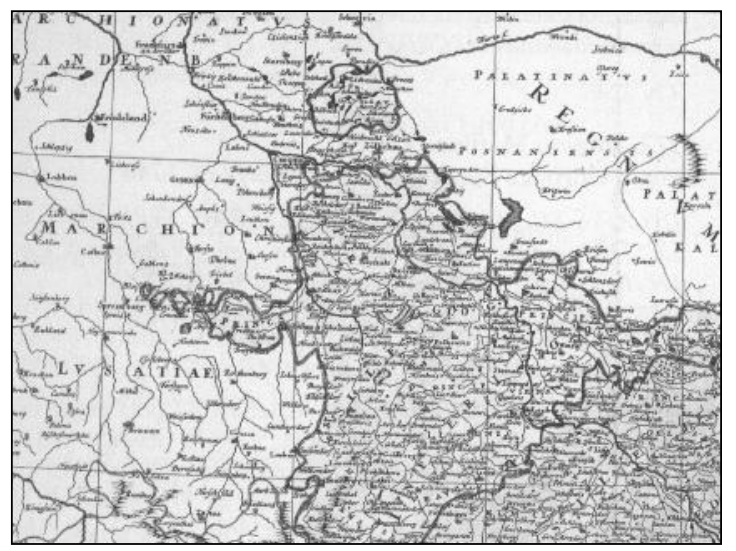

Fig. 12. Fragment of the Silesia map by T. Meyer

Wrocław from 1741 placed on the maps of regions. The first one comes from the semithematic map of Silesia presenting the region as a theater of military operations. Its author was Georges Louis Le Rouge - a French cartographer ${ }^{30}$. At the bottom of the map, on the left, in box one can see a realistic miniature of the Wrocław plan (Fig. 13).

\footnotetext{
${ }^{26}$ R. Wytyczak, Śląsk w dawnej kartografii, p. 65

${ }^{27} \mathrm{~J} . \mathrm{B}$. Harley, Maps, knowledge and power, in: The iconography of landscape: Essays on the symbolic presentation, design and use of past environments, ed. D. Cosgrove, D. Stephen, Cambridge 1988, p. 279.

${ }_{28}$ M. Dworsatschek, Imago Silesiae. Z kolekcji Tomasza Niewodniczańskiego, Wrocław 2002, p. 110.

${ }^{29}$ R. Wytyczak, Śląsk w dawnej kartografii, p. 70.

${ }^{30}$ M. Dworsatschek, Imago Silesiae, p. 78, pos. 102.
} 


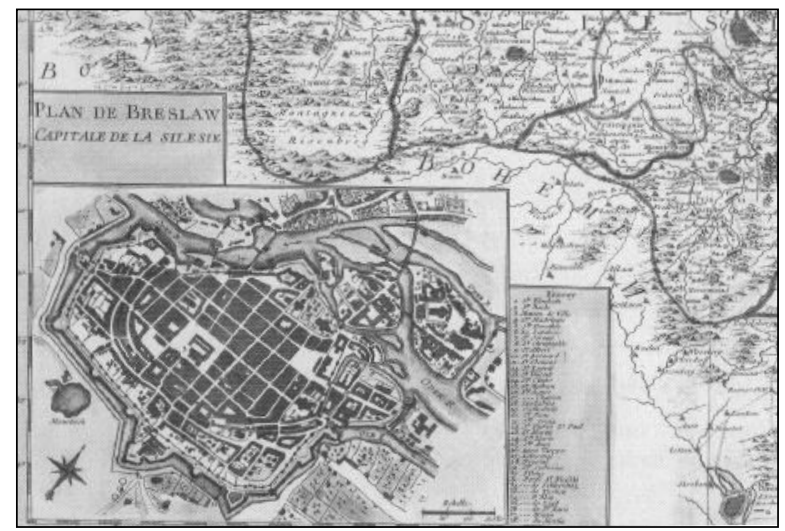

Fig. 13. Fragment of the Silesia map by G.L. Le Rouge

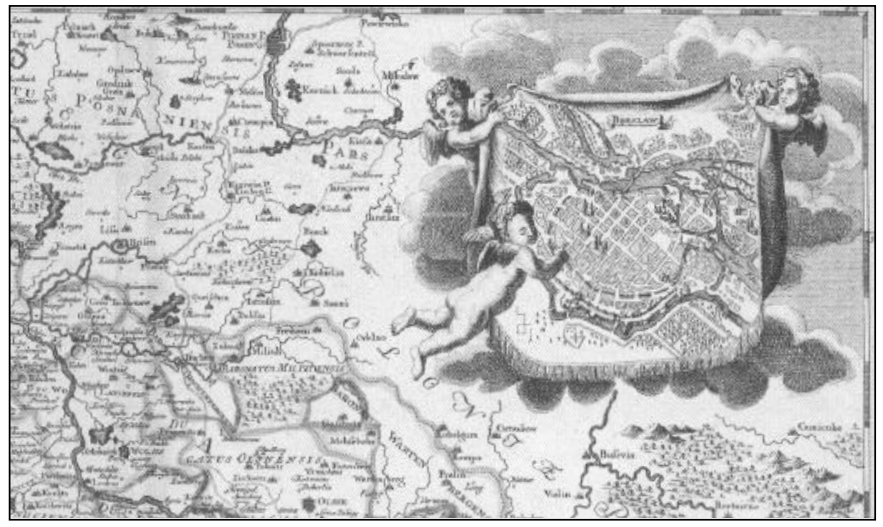

Fig. 14. Fragment of the Silesia map by J. Covens and C. Mortier

Another equally miniature image of the city was placed by Johannes Covens and Cornelius Mortier on their map of Silesia ${ }^{31}$. In the upper right corner, three putti unroll a plan of Wrocław (Fig. 14). Although it brings closer not only the shape but also city planning there is no doubt that it is the visualization in a cartouche which seems to be of more symbolic than realistic dimension.

\section{Conclusion}

All the subjects on the frontier of different disciplines are usually interesting from the researcher's point of view but at the same time they are quite difficult to interpret and may not always seem to be attractive. The juxtaposition of cartography and widely known humanities seems to confirm this assumption especially when the topic is formulated as in this paper. However, the analysis of several examples which bring closer the phenomenon of the presence of the cultural content in the space records on the maps of Silesia (from the $16^{\text {th }}$ to the late $18^{\text {th }}$ centuries), allows to draw a number of general observations and conclusions:

1. The material allows to extend the knowledge about the social roots of the map. Nowadays people look at human needs (which are associated with the formation and improvement of maps in the course of centuries) mostly from the utilitarian, less cultural perspective. That thematic approach allows people to spot spiritual and immaterial aspects as well that may not determine the decision whether one should or should not start working on the map. However, there were parts of the map where those aspects became visible and even significant.

2. The maps and plans of Silesian cities (from the late-feudal period) complement the knowledge (acquired by other research disciplines) on the rank of the region, its material and cultural wealth and the fully formed regional consciousness of its inhabitants.

3. The examples that were presented enabled to discover how cartographers of Silesia co-created the image of the region which is not only culturally rich but also proud of its history and open to the use its potential.

4. The examples of the symbolic space in the old Silesian cartography also allowed to indicate one of the important problems (concerning the formation of the regional or local specific character) - the impact of spatial conditions on the contents and forms of cultural transfers (to which the old cartographic work can be unquestionably classified).

${ }^{31}$ M. Dworsatschek, Imago Silesiae, p. 75, pos. 98. 


\section{Bibliography}

Barttomieja Steina renesansowe opisanie Wroctawia. Die Beschreibung der Stadt Breslau der Renaissancezeit durch Bartholomäus Stein, ed. R. Żerelik, Wrocław 1995.

Bogacz T., Cetwiński M., Kościk E., Wroctawskie anegdoty, Wrocław 1996.

Bogacz T., Konopska B., Motywy kartograficzne $w$ medalierstwie polskim, in: Dwudziestolecie Zespotu Historii Kartografii przy Instytucie Historii Nauki PAN, ed. J. Ostrowski, W. Wernerowa, Warszawa 1995 („Z Dziejów Kartografii", t. 7), pp. 99-124.

Brzezowki W., Ogrody barokowego Wroctawia, „Architectus”, 2003, no 1-2, pp. 69-82.

Czechowicz B., Historia kartografi Ślaska XIIIXIX wieku, Wrocław 2004.

Dworsatschek M., Imago Silesiae. Z kolekcji Tomasza Niewodniczańskiego, Wrocław 2002.

Encyklopedia Wroctawia, ed. J. Harasimowicz, Wrocław 2006.

Geremek B., Relacja Jakuba Esprincharda z podróży przez Ślask i Matopolskę, „Kwartalnik Historii Kultury Materialnej”, 7 (1959), no 3, pp. 438-453.

Gładkiewicz R., Dzieje Ztotoryi, ZłotoryjaWrocław 1997.

Harley J.B., Maps, knowledge and power, in: The iconography of landscape: Essays on the symbolic presentation, design and use of past environments, ed. D. Cosgrove, D. Stephen, Cambridge 1988, pp. 277-312.

Janczak J., Karol Hentschel ojciec ślaskiej kartografii gospodarczej. „Informator Krajoznawczy”, 1990, no 57, pp. 3-9.

Janczak J., Spotkania z Duchem Gór. Sudeckie szkice historyczne, Wrocław 1991.
Janczak J., Z kuferkiem i chlebakiem. Kartki o przesztości uzdrowisk i turystyki ślaskiej, Wałbrzych 1982.

Janczak J., Zarys dziejów kartografii ślaskiej do końca XVIII wieku, Opole 1976.

Janczak J., Ztotoryja i jej okolice na najstarszych mapach Ślaska, Legnica-Złotoryja 1984.

Małachowicz E., Najnowszy zarys dziejów najstarszego Wroctawia, Wrocław 2000.

Monnet J., The symbolizm of place: a geography of relationships between space, power and identity. „Cybergeo: European Journal of Geography", article 562 (http://cybergo.revues. org/24747, 3 IV 2013).

Oszczanowski P., Wroctawski ogród Laurentiusa Scholtza St. (1552-1599), in: Ślaska Republika Uczonych. Schlesische Gelehrtenrepublik. Slezská Védecká Obec, vol. 1, ed. M. Hałub, A. Mańko-Matysiak, Wrocław 2004.

Polska Jana Dtugosza, red. H. Samsonowicz, Warszawa 1984.

Przybytek D., Kartografia historyczna Ślaska XVIII-XX wieku, Wrocław 2002.

Scheuermann G., Das Breslau Lexicon, Bd 2, Dülmen 1994.

Szykuła K. i in., Wroctaw na planach. XVI-XX wiek, ed. H. Okólska, Wrocław 1999.

Trzciński M., Miecz katowski, pregierz, szubienica. Zabytki jurysdykcji karnej na Dolnym Ślasku (XIII-XVIII w.), Wrocław 2001.

Wytyczak R., Ślask w dawnej kartografii. Obraz Ślaska na mapach XVI-XVIII wieku w zbiorach Zaktadu Narodowego im. Ossolinskich we Wroctawiu, Wrocław 1998.

\section{Przestrzeń symboliczna na dawnych mapach Śląska (XVI-XVIII w.)}

\section{Streszczenie}

Z przestrzenią symboliczną wiąże się zazwyczaj treści kulturowe i duchowe, znajdujące odzwierciedlenie w zapisie czy krajobrazie przestrzennym. Dotyczą one - między innymi - pielęgnowania przeszłości i tradycji, wzmac- niania lub budowania identyfikacji z terenem, tworzenia jego lokalnej specyfiki, poszukiwania i odkrywania kulturowej tożsamości. Przestrzeń symboliczna $\mathrm{z}$ wpisanym kodem semantycznym i aksjologicznym znalazła swoje 
miejsce także w europejskiej kartografii regionalnej, od najwcześniejszych map poczynając. Szczególnie ciekawie zaznaczyła swą obecność na mapach regionów historyczno-geograficznych, ukształtowanych w naturalnym procesie rozwojowym. Ich mieszkańcy, posiadając wysoki stopień regionalnej świadomości i znaczący dorobek kulturowy, czuli potrzebę przestrzennego zobrazowania tych wartości. Do takich obszarów zaliczał się Śląsk.

W artykule na przykładzie map Śląska od XVI do XVIII w. pokazano różnorodne przykłady realizacji tej specyficznej potrzeby zaznaczania kulturowej odrębności. Podporząakowano je hasłom, które złożyły się na układ treści. Pierwsze z nich zobrazowało ambicje oświatowe i intelektualne Ślązaków na przykładzie informacji o pierwszej szkole, zamieszczonej na mapie M. Helwiga i korekty tego przekazu na pierwszej mapie gospodarczej regionu K.F Hentschela. Kolejno przybliżono społeczne potrzeby: kulturowej identyfikacji $\mathrm{z}$ terenem, pamięci o wartościach duchowych i materialnych, dumy z egzekwowania prawa (na przykładzie planów Głogowa i Wrocławia) oraz kształtowania legendy miejsc, które stawały się wizytówką lokalnej społeczności (ogród Scholtza we Wrocławiu). Wskazano także na pojawiające się na mapach przejawy resentymentów politycznych, związanych ze zmianami granic Śląska (enklawa świebodzińska na mapie J.J. Lidla).

Przedstawione przykłady pozwoliły również na zasygnalizowanie szerszego problemu badawczego - wpływu uwarunkowań przestrzennych na treści i formy przekazów kulturowych, do jakich niewątpliwie należy dawna twórczość kartograficzna.

Słowa kluczowe: historia kartografii, dawne mapy Śląska, przestrzeń symboliczna.

Keywords: history of cartography, old maps of Silesia, symbolic space.

dr Teresa Bogacz - adiunkt w Katedrze Turystyki Wyższej Szkoły Zarządzania „Edukacja” we Wrocławiu, członek Zespołu Historii Kartografii przy Instytucie Historii Nauki PAN, (e-mail: teresa.bogacz@wp.pl). 